\title{
Decreased plasma epidermal growth factor (EGF) levels in patients with severe chronic obstructive pulmonary disease
}

Retno AS Soemarwoto ${ }^{1}$, Jamsari $^{2}$, Yanwirasti ${ }^{3}$, Andika Chandra Putra ${ }^{4, t}$, Syazili Mustofa ${ }^{5}$

${ }^{1}$ Biomedical Sciences Post-Graduate Programme, Faculty of Medicine, Universitas Andalas, Padang, Indonesia

${ }^{2}$ Faculty of Agriculture, Universitas Andalas, Padang, Indonesia

${ }^{3}$ Department of Anatomy, Faculty of Medicine, Universitas Andalas, Padang, Indonesia

${ }^{4}$ Department of Pulmonology and Respiratory Medicine, Faculty of Medicine, Persahabatan Hospital, Universitas Indonesia, Jakarta, Indonesia

Abstract

${ }^{5}$ Department of Biochemistry, Molecular Biology, and Physiology, Faculty of Medicine, Universitas Lampung, Bandar Lampung, Indonesia

English:

Background: Chronic mucus hypersecretion is a common feature in chronic obstructive pulmonary disease (COPD) and is associated with epidermal growth factor (EGF) activity. Aberrant EGF and its receptor signalling can cause airway hyperproliferation, increase in mucous cell differentiation and mucus hyperproduction. Furthermore, it can also promote subepithelial fibrosis and excessive collagen deposition in COPD. The objective of this research was to investigate the plasma levels of EGF in smokers with COPD in comparison with clinically healthy smokers. In addition, the relationship between the plasma levels of EGF and clinical features was investigated.

Methods: A cross-sectional study included 82 clinically stable male patients with mild-to-very severe COPD (mean age: $64.5 \pm 8.6$ years), and the control group consisted of 86 healthy male smokers (mean age: 61.6 \pm 9.5 years). To define COPD, we performed spirometry and classified COPD using Global Initiative for Chronic Obstructive Lung Disease (GOLD) classification. We analyzed the levels of EGF by enzyme-linked immunosorbent assay in plasma.

Results: The mean serum levels of EGF were significantly lower in smokers with COPD than those in controls $(69.30 \mathrm{and} 83.82 \mathrm{pg} / \mathrm{mL}$, respectively, $p=0.046)$. The plasma levels of $E G F$ were significantly different $(p=0.004)$ between mild COPD and moderate-to-very severe COPD. There were no significant differences between the levels of EGF in plasma of spontaneous sputum producers (COPD patients) vs. nonsputum producers $(p=0.101)$ and between nonexacerbated COPD and exacerbated COPD patients $(p=0.138)$.

Conclusions: There is a significant difference in the plasma levels of EGF in male smokers with COPD as compared with male healthy smokers. Our findings suggest that the plasma levels of EGF may contribute to the pathogenesis of COPD.

Keywords

COPD $\cdot$ plasma levels of EGF $\cdot$ smokers $\bullet$ mucous hypersecretion $\cdot$ exacerbation $\bullet$ spirometry

\section{Nivelul plasmatic al factorului de creștere epidermal (EGF) este scăzut la pacienții cu BPOC sever}

Rezumat

\section{Romanian: \\ Introducere}

Hipersecretia cronică de mucus este o trăsătură obișnuită a bronhopneumopatiei obstructive cronice (BPOC) și este asociată activității factorului de creștere epidermal (EGF). EGF́ aberant și semnalizarea receptorului său poate genera hiperproliferare în căile aeriene, creștere a diferențierii celulelor mucoase și hiperproducția de mucus. Mai mult, poate stimula fibroza subepitelială și depunerea excesivă de colagen în BPOC. Obiectivul acestei cercetări a fost investigarea nivelurilor plasmatice ale EGF la fumători cu BPOC în comparație cu fumători clinic sănătoși, ca și relația între nivelul plasmatic al EGF și caracteristicile clinice.

Metodă

Un studiu încrucișat a inclus 82 de pacienți de sex masculin cu BPOC ușor până la foarte sever, stabil (vârsta medie $64.5 \pm 8.6$ ani), grupul control fiind alcătuit din 86 bărbați fumători sănătoși (vârsta medie $61.6 \pm 9.5$ ani). BPOC a fost definit prin spirometrie și clasificat pe baza criteriilor GOLD. Am analizat nivelul EGF prin ELISA în plasmă.

${ }^{+}$Corresponding author: Andika Chandra Putra

E-mail: andikacppulmo@gmail.com 


\section{Rezultate}

Nivelul mediu plasmatic al EGF a fost semnificativ mai scăzut la fumătorii cu BPOC decât la grupul control $69.30 \mathrm{pg} / \mathrm{ml}$, și respectiv $83.82 \mathrm{pg} / \mathrm{ml}, p=0.046)$. Nivelul plasmatic al EGF a fost semnificativ diferit ( $p=0.004$ ) între BPOC ușor și BPOC moderat până la foarte sever. Nu au fost diferente semnificative între nivelul plasmatic EGF la pacienții cu productie de spută vs cei fără productie de spută ( $p=0.101)$ și între none-exacerbatori și exacerbatori $(p=0.138)$.

Concluzii

s-a observat o diferență semnificativă între nivelurile plasmatice ale EGF la bărbații fumători cu BPOC față de bărbații fumători sănătoși. Rezultatele sugerează că nivelul plasmatic al EGF ar putea contribui la patogeneza BPOC.

Cuvinte-cheie

$B P O C \cdot$ nivel plasmatic EGF • fumători $\bullet$ hipersecreție de mucus $\bullet$ exacerbare $•$ spirometrie

\section{Introduction}

Chronic obstructive pulmonary disease (COPD) is one of the world's major health problems. COPD is a silent killer in low and middle-income countries. An estimated 328 million people have COPD worldwide. It is already the third leading cause of death worldwide (1). COPD is characterized by chronic airflow limitation caused by a combination of small airway inflammation and parenchymal destruction $(2,3)$.

Furthermore, abnormalities in COPD develop slowly and usually become apparent after 40 or 50 years of age. The most common symptoms of COPD are breathlessness, chronic cough and sputum production (4). Daily activities can become very difficult as the condition gradually worsens. Subjects with COPD also frequently experience exacerbations, that is, serious episodes of increased breathlessness, cough and sputum production that last from several days to a few weeks (5). Airway mucus hypersecretion is a serious and presently untreatable symptom of COPD. Activated neutrophils recruited to the airways (and their secreted products) play several key roles in mucus hypersecretion. Enhancement of neutrophil function by the bronchial epithelium is stimulated by epidermal growth factor (EGF) $(6,7)$.

Related to this, EGF influences the proliferation of many lung structural cells, such as fibroblasts, airway smooth muscle cells and the turnover of matrix proteins. They may be involved in airway repair and remodelling processes (8). Binding of EGF to the EGF receptor (EGFR) leads to the activation of several key downstream signalling pathways (9). Activation of these pathways leads to cell proliferation, adhesion, migration and angiogenesis. Aberrant expression of growth factors is linked to tissue remodelling in response to cigarette smoke in COPD patients (10).

In line to hypersecretion, mucin production is activated in part by the stimulation of the EGFR pathway through neutrophils and macrophages. Levels of EGFRs are higher in COPD patients (11). EGF and EGFR are important players in regulating mucus production in airway epithelium and in the repair of epithelium after injury. They were found to be involved in activation leading to mucin production in response to noxious stimuli $(8,12)$. It is suggested that disrupting the EGFR cascade that leads to mucus production is beneficial in airway inflammatory (hypersecretory) diseases (13). How circulating EGF levels relate to COPD is not clear.

Therefore, we conducted this cross-sectional study to investigate whether healthy smokers and smokers with COPD express different plasma EGF levels that could explain their increased risk of COPD. Two distinct groups were selected for the purpose of comparing cytokine profiles: a study group of smokers with COPD and a control group of healthy smokers.

\section{Methods}

This research was a cross-sectional observational study. It involved COPD male smoker patients who were randomly selected from Harum Melati Pulmonology Clinic and male healthy smokers who lived around Pringsewu district, Lampung Province, Indonesia. The study was conducted from January 2018 to October 2018. Participants were at least 40 years old and had a smoking history (evaluated by the Brinkman Index: the number of cigarettes smoked per day multiplied by the number of years of smoking), and they had no clinical manifestations of lung cancer, infections and other lung diseases. All of them performed spirometry at enrolment and at baseline and completed standardized questionnaires including socio-demographic information and smoking history.

\section{Spirometry testing}

According to the Pneumobile Indonesian Lung Health Survey (14), lung function was measured at baseline in all study participants using a flow spirometer (CHESTGRAPH HI 101; Chest MI, Inc, Tokyo, Japan). Forced expiratory volume in one second $\left(\mathrm{FEV}_{1}\right)$ and forced vital capacity $(\mathrm{FVC})$ values were expressed as a percentage of the predicted value, according to the standard spirometric reference values for 
the Indonesian population (14). In this view, the diagnosis of airflow obstruction is based on a specific cut point for the $\mathrm{FEV}_{1} / \mathrm{FVC}$ ratio of $<0.76$ (absolute value) after bronchodilator and $\mathrm{FEV}_{1}<80 \%$ predicted (Table 1 ).

Based on the reference above, male subjects over 50 years old with a post-bronchodilator $\mathrm{FEV}_{1} / \mathrm{FVC}$ ratio of $<76 \%$ were classified as having airway obstruction (14). On the other hand, after the obstruction was diagnosed, the classification of airway limitation severity in COPD was categorized based on the Global Initiative for Chronic Obstructive Lung Disease (GOLD) (2).

One hundred and sixty-eight current and former smokers participated in this study and lung function test was performed in all of them. All subjects were male. No differences were observed for age, and cumulative tobacco exposure at the time of the evaluation was observed between the COPD and control groups. Subjects with COPD had lower absolute values of $\mathrm{FEV}_{1}, \mathrm{FVC}$ and $\mathrm{FEV}_{1} / \mathrm{FVC}$ ratio. Patient characteristics and physiological measurements of both groups are summarized in Table 2.

\section{Determination of plasma levels of EGF}

All of the participants' blood was collected into Vacutainer ${ }^{\circledR}$ tubes. Blood specimens were centrifuged $(2,000 \times g)$, and aliquots stored at -80 until laboratory analysis was performed. Plasma levels of EGF were measured using Quantikine ${ }^{\circledR}$ ELISA Human EGF (R\&D Systems, Inc., Minneapolis, USA; Cat: DEG00, Lot: P165621, ED: 21 May 2019) following the manufacturer's instructions. The detection limits were $0.266 \mathrm{pg} / \mathrm{mL}$. A Microplate Reader Bio-Rad model

Table 1. Diagnosis of airflow obstruction according to Pneumobile Project, Indonesia.

\begin{tabular}{lcc}
\hline & FEV $_{1}$ predicted (\%) & FEV $_{\mathbf{1}}$ /FVC (\%) \\
\hline Normal airflow & $\geq 80$ & $\geq 76$ \\
Airflow obstruction & $<80$ & $>76$ \\
\hline
\end{tabular}

$\mathrm{FEV}_{1}$, forced expiratory volume in one second; FVC, forced vital capacity.

Table 2. Clinical and physiological characteristics of smokers with COPD vs healthy smokers

\begin{tabular}{lccc}
\hline & $\begin{array}{c}\text { Male smokers } \\
\text { with COPD }\end{array}$ & $\begin{array}{c}\text { Male healthy } \\
\text { smokers }\end{array}$ & $\boldsymbol{p}$ \\
\hline Age (SD) (years) & $64.5(8.6)$ & $61.6(9.5)$ & 0.79 \\
Brinkman Index (SD) & $409.6(199.22)$ & $426.14(243.14)$ & 0.632 \\
$\mathrm{FEV}_{1}{ }^{*}$ (SD) & $55.40(20.47)$ & $103.81(20.07)$ & 0.000 \\
$\mathrm{FVC}^{*}$ (SD) & $74.50(19.49)$ & $94.64(16.18)$ & 0.000 \\
$\mathrm{FEV}_{1}$ /FVC (SD) & $73.24(14.51)$ & $110.64(18.64)$ & 0.000 \\
\hline
\end{tabular}

*Percentage of predicted value.

COPD, chronic obstructive pulmonary disease; $\mathrm{FEV}_{1}$, forced expiratory volume in one second; FVC, forced vital capacity.
680 (Bio-Rad Laboratories Inc, CA, USA) with software Microplate Manager version 5.2.1 (Bio-Rad Laboratories Inc., CA, USA) was used to read the samples, compute standard curves, and estimate cytokine concentrations. The tests were performed at Prodia Laboratory (Jakarta, Indonesia).

Statistical analysis: Quantitative measurements were presented as mean $( \pm S D)$. Categorical variables were shown along with their percentages. Comparisons between groups were made using $t$-independent or Mann-Whitney test. EGF levels were not normally distributed. Univariate analyses were performed, values of plasma EGF level as the dependent variable and individual variables as independent variables. Significance was established as a two-tailed $p$-value of $<0.05$ for all the analyses. Calculations were made using statistical software (IBM SPSS Statistic).

\section{Ethical consideration}

This study was approved by the ethical committee of the Faculty of Medicine, Universitas Lampung. Written consent was obtained from all patients, and they were ensured about confidentiality and security of their personal information.

\section{Results}

Baseline characteristics of the subjects are listed in Table 2. The COPD subjects included in this study were generally similar to the controls but slightly older and had lower Brinkman Index. There were significant differences in pulmonary function between the male COPD smokers and the control male healthy smokers. In terms of EGF level, there was a significant difference of EGF level in COPD patients as compared to controls. COPD patients had a significantly lower mean level of plasma EGF as compared to controls (69.30 pg/ $\mathrm{mL}$ in COPD patients and $83.82 \mathrm{pg} / \mathrm{mL}$ in healthy smokers, $p=0.046$; Table 3).

Furthermore, we performed the comparison analysis between univariate for the plasma levels of EGF and potential confounding variables as summarized in Table 4. We suggested that the plasma level of EGF from mild airflow limitation (GOLD 1) was noticeably higher than moderateto-very severe airflow limitation (GOLD 2-4). In addition, the distribution of EGF values in the subgroups of patients as shown in Figure 1. Moreover, there were no significant

Table 3. Plasma EGF levels in COPD smokers vs. healthy smokers.

\begin{tabular}{lcccc}
\hline Group & N & Mean $(\mathbf{p g} / \mathrm{mL})$ & SD & $\boldsymbol{p}$ \\
\hline COPD smokers & 82 & 69.305 & 61.452 & 0.046 \\
Healthy smokers & 86 & 83.822 & 63.927 & \\
\hline
\end{tabular}

COPD, chronic obstructive pulmonary disease; EGF, epidermal growth factor. 
Table 4. Univariate analysis for plasma EGF levels and potential confounding variables.

\begin{tabular}{lccc}
\hline Variables & N & $\begin{array}{c}\text { Mean plasma level of } \\
\text { EGF (SD) }\end{array}$ & p \\
\hline Airflow limitation severity & & & \\
GOLD 1 (mild) & 10 & $62.204(56.08)$ & \\
GOLD 2-4 (moderate-very & 72 & & \\
severe) & & & \\
Sputum production & & & \\
Nonspontaneous & 35 & $60.1 .50(64.56)$ & \\
Spontaneous & 42 & & \\
COPD exacerbation in & & & \\
previous year & & $76.35(63.02)$ & 0.138 \\
No exacerbation & 50 & $58.29(58.17)$ & \\
Exacerbation & 32 & & \\
\hline
\end{tabular}

COPD, chronic obstructive pulmonary disease; EGF, epidermal growth factor; GOLD, Global Initiative for Chronic Obstructive Lung Disease.

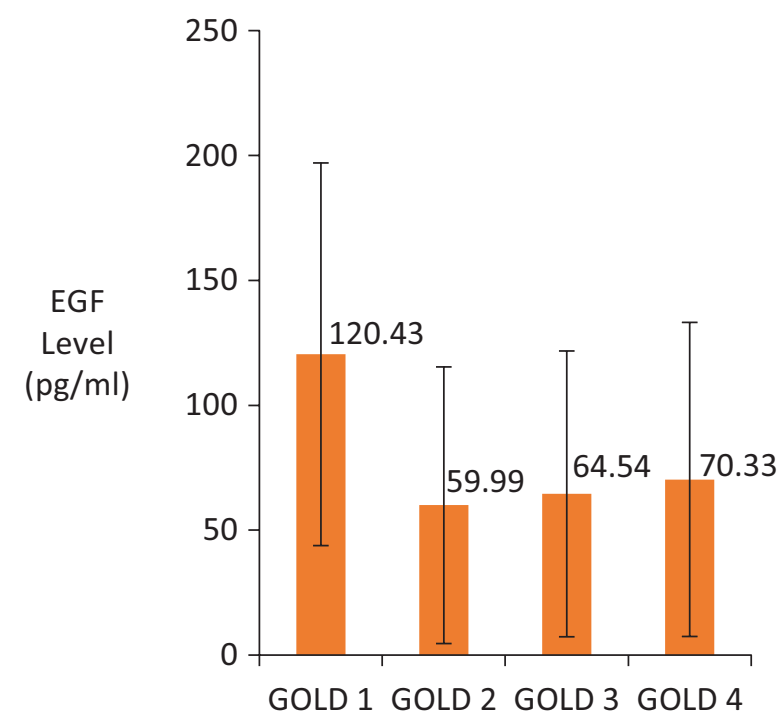

Figure 1. Distribution of EGF values in subgroups of patients EGF, epidermal growth factor.

differences of the plasma EGF level in patients with sputum production and COPD exacerbation in the COPD group.

\section{Discussion}

In this study, we determined the airway obstruction based on the normal pulmonary value of Indonesian population. Using the normal values of lung function of other countries would certainly not be the right decision, because it will change the value of predictions and the conclusions could be not be valid. Of several publications, the most representative for the pulmonary physiology of Indonesians are the results of the Pneumobile Team research conducted in Jakarta and Surabaya with a total sample of 4,118 people. The procedure of this study was adjusted to the recommendations of the American Thoracic Society (ATS). So that it could be compared if there were other researchers who would carry out the same research. By providing Indonesian lung standard values, we can diagnose airflow obstruction effectively for Indonesian population. According to this survey, the normal absolute value of FEV1/FVC ratio in men over the age of 51 years is $76 \%$. Therefore, in that age, the value of FEV1/FVC that was $<76 \%$ was categorized as obstruction. It is different from GOLD criteria that determine the diagnosis of COPD with an $\mathrm{FEV}_{1} / \mathrm{FVC}$ value of $<70 \%$. Therefore, we used this step because the value of lung function based on GOLD criteria was not appropriate when conducted in Indonesia. The value of lung function is strongly influenced by ethnicity, habits, and environment (14).

In the case of EGF, it was demonstrated that it stimulates human airway smooth muscle proliferation (15). An increased EGF expression was reported in the epithelium and submucosal cells of patients with chronic bronchitis (16). This growth factor was a ligand for the EGFR that was synthesized as transmembrane precursors and subsequently released by proteolytic cleavage as biologically active mature proteins. EGF has been shown to participate in epithelial repair processes and airway remodelling both in vitro and in vivo in models of lung disease (17).

The main finding of this study showed that smokers with COPD have lower plasma levels of EGF as compared to healthy smokers. The lower plasma levels of EGF may result in the activation of a combination of small airway inflammation and parenchymal destruction. It was shown that there is a higher EGFR expression in intact lung epithelium and higher EGF level expression in damaged lung epithelium of ex-smokers with COPD compared with former smokers without COPD (11). But in our finding, plasma level of EGF in COPD patients was lower. A possible explanation for this decrease was caused by epithelial repair which was disturbed in patients with COPD owing to higher expression of EGF the lung and overused EGF in plasma. Consistent with our result, a study in smokers by using computed tomography which detected emphysema and no airway obstruction showed decreased plasma levels of EGF (18).

In the present study, the plasma EGF level in mild airflow limitation was found higher than moderate to very severe airflow limitation. This is in contrast to the finding of Cockayne et al. who reported an increased serum heparin-binding EGF (HB-EGF) being associated with COPD disease severity (19). There were highly elevated circulating levels of EGF in the 
serum samples of COPD patients, with a median of $>50$-fold increase over levels in controls.

Generally, the demand for EGF in COPD is increased. This was supported by other researchers who showed that EGF has been reported to be elevated in the bronchial epithelial cells of COPD patients (20), particularly in damaged epithelia (11). HB-EGF contributes to COPD disease severity by modulating airway fibrosis and pulmonary epithelial-mesenchymal transition (10).

Furthermore, the study by Cornwell et al. who investigated COPD associated with bronchoalveolar lavage levels of EGF (21). Sputum HB-EGF expression was significantly increased in patients with COPD compared with nonsmokers and smokers without COPD. There was a significant positive correlation between sputum HB-EGF and COPD assessment test (CAT) score. HB-EGF expression was significantly increased in the lung tissue samples of patients with COPD and associated with collagen deposition and $\mathrm{N}$ - and $\mathrm{E}$-cadherin, and vimentin expression. In vitro, HB-EGF promoted collagen production in lung fibroblasts. Moreover, HB-EGF induced the EMT process through induction of $\mathrm{N}$ - and $\mathrm{E}$-cadherin, and vimentin expression in HBE cells. Collectively, HB-EGF induces airway remodelling by modulating airway fibrosis and pulmonary EMT and contributes to the COPD severity (22). Although the production of EGF is increased, it seems that the epithelium needs it for repairing. Therefore, a great amount of EGF is used, causing a decrease in the blood level. It conclusion was supported by the current study.

In this study, there was no significant difference in the plasma level of EGF in patients with increased sputum production and COPD exacerbation. On the contrary, EGF can increase the expression of MUC5AC, a mucin associated with airway obstruction in COPD (23). EGF also activates fibroblasts and stimulates their proliferation (20), however, cigarette smoke, in the absence of the clinical presentation of COPD, it has been implicated in mucus production in airways via activation of the EGFR $(24,25)$. Smoking upregulates a systemic pattern of neutrophil and macrophage chemoattractant expression, and it was correlated significantly with the development of goblet cell hyperplasia (26).

\section{Conclusions}

We conclude that smokers with COPD have a distinct EGF plasma profile when compared to smoker subjects without COPD. Lower levels of EGF may be involved in airway epithelial repair and airway remodelling, mechanisms that lead to a higher COPD risk. Larger prospective studies are needed to support our findings, and to investigate whether other discordant cytokine profiles might clarify for variations in the systemic manifestations within a given population.

\section{Acknowledgement}

The authors thank Fariz Nurwidya, MD, PhD, Universitas Indonesia, for his support; all the members in the Harum Melati Pulmonology Clinic, Pringsewu district; and all the staff in the Department of Pulmonology and Respiratory Medicine, Abdul Moeloek Hospital, Universitas Lampung, Lampung Province, Indonesia.

\section{Ethics approval and consent to participate}

The study protocol was approved by the institutional ethics committee of the Faculty of Medicine, University of Lampung. All subjects signed an informed consent prior to participation.

\section{Competing interests}

The authors declare that they have no competing interests.

\section{Funding}

This work was personally funded without any grant.

\section{References}

1. Quaderi SA, Hurst JR. The unmet global burden of COPD. Global Health, Epidemiology and Genomics. 2018;3:e4-e4.

2. Vestbo J, Hurd SS, Agusti AG, Jones PW, Vogelmeier C, Anzueto $A$, et al. Global strategy for the diagnosis, management, and prevention of chronic obstructive pulmonary disease: GOLD executive summary. American Journal of Respiratory and Critical Care Medicine. 2013;187(4):347-365.

3. Bradford E, Jacobson S, Varasteh J, Comellas AP, Woodruff P, O'Neal W, et al. The value of blood cytokines and chemokines in assessing COPD. Respiratory Research. 2017;18(1):180.

4. Hogg JC, Paré PD, Hackett T-L. The contribution of small airway obstruction to the pathogenesis of chronic obstructive pulmonary disease. Physiological Reviews. 2017;97(2):529-552.

5. Koo H-K, Park S-W, Park J-W, Choi HS, Kim TH, Yoon HK, et al. Chronic cough as a novel phenotype of chronic obstructive pulmonary disease. International Journal of Chronic Obstructive Pulmonary Disease. 2018;13:1793-1801.

6. Uddin M, Seumois G, Lau LC, Rytila P, Davies DE, Djukanović R. Enhancement of neutrophil function by the bronchial epithelium stimulated by epidermal growth factor. European Respiratory Journal. 2008;31(4):714-724.

7. Rezaeetalab F, Dalili A, Alamdari DH. Prooxidant - antioxidant balance in COPD patients. Pneumologia. 2017;66(2):90-93. 
8. Burgel PR, Nadel JA. Roles of epidermal growth factor receptor activation in epithelial cell repair and mucin production in airway epithelium. Thorax. 2004;59(11):992-996.

9. Broekman W, Amatngalim GD, de Mooij-Eijk Y, Oostendorp J, Roelofs $\mathrm{H}$, Taube $\mathrm{C}$, et al. TNF-alpha and IL-1beta-activated human mesenchymal stromal cells increase airway epithelial wound healing in vitro via activation of the epidermal growth factor receptor. Respiratory Research. 2016;17:3.

10. Wang Q, Li H, Yao Y, Xia D, Zhou J. The overexpression of heparin-binding epidermal growth factor is responsible for Th17induced airway remodeling in an experimental asthma model. The Journal of Immunology. 2010;185(2):834-41.

11. de Boer WI, Hau CM, van Schadewijk A, Stolk J, van Krieken $\mathrm{JH}$, Hiemstra PS. Expression of epidermal growth factors and their receptors in the bronchial epithelium of subjects with chronic obstructive pulmonary disease. American Journal of Clinical Pathology. 2006;125(2):184-192.

12. Takeyama K, Jung B, Shim JJ, Burgel PR, Dao-Pick T, Ueki IF, et al. Activation of epidermal growth factor receptors is responsible for mucin synthesis induced by cigarette smoke. American Journal of Physiology-Lung Cellular and Molecular Physiology. 2001;280(1):L165-L172.

13. Shaykhiev R, Zuo W-L, Chao IW et al. Distal-to-proximal remodeling of small airway epithelium in smokers mediated by EGF signaling in small airway basal progenitor cells. In: A19 Pathologic Programming Of Airway Epithelium. edn.; 2015; A1050-A1050.

14. Alsagaff $\mathrm{H} \mathrm{MH}, \mathrm{Amin} \mathrm{M}$, Yunus $\mathrm{F}$ et al. Reference spirometric values of healthy Indonesian schoolchildren and working adults, using equipment and methods that meet ATS 1987 recommendations. Paru 1992;12(4):3-18.

15. Hirst SJ, Barnes PJ, Twort CHC. Quantifying proliferation of cultured human and rabbit airway smooth muscle cells in response to serum and platelet-derived growth factor. American Journal of Respiratory Cell and Molecular Biology. 1992;7(6):574-581.

16. Vignola AM, Chanez P, Chiappara G, Merendino A, Pace E, Rizzo A, et al. Transforming growth factor- $\beta$ expression in mucosal biopsies in asthma and chronic bronchitis. American Journal of Respiratory and Critical Care Medicine. 1997;156(2): 591-599.
17. Wang Q, Li H, Yao Y, Lu G, Wang Y, Xia D, et al. HB-EGF-promoted airway smooth muscle cells and their progenitor migration contribute to airway smooth muscle remodeling in asthmatic mouse. The Journal of Immunology. 2016;196(5):2361-2367.

18. de-Torres JP, Blanco D, Alcaide AB, Seijo LM, Bastarrika G, Pajares MJ, et al. Smokers with CT detected emphysema and no airway obstruction have decreased plasma levels of EGF, IL-15, IL-8 and IL-1ra. PLoS One. 2013;8(4):e60260.

19. Cockayne DA, Cheng DT, Waschki Betal. Systemic biomarkers of neutrophilic inflammation, tissue injury and repair in COPD patients with differing levels of disease severity. PLoS One. 2012;7(6):e38629.

20. Chung KF. Cytokines in chronic obstructive pulmonary disease. European Respiratory Journal. 2001;18(1):50-59.

21. Cornwell WD, Criner GJ, Oros $M$ et al. Induction of Epidermal Growth Factor and Interleukins 1, 8, and 9 Expression in the Lungs in Chronic Bronchitis and Chronic Obstructive Pulmonary Disease. In: B37 TELL ME WHY: COPD PATHOGENESIS. edn.: A2906-A2906.

22. Lai T, Li Y, Chen M, Pan G, Wen X, Mai Z, et al. Heparinbinding epidermal growth factor contributes to COPD disease severity by modulating airway fibrosis and pulmonary epithelial-mesenchymal transition. Laboratory Investigation. 2018;98(9):1159-1169.

23. Mata M, Sarriá B, Buenestado A, Cortijo J, Cerdá M, Morcillo EJ, et al. Phosphodiesterase 4 inhibition decreases MUC5AC expression induced by epidermal growth factor in human airway epithelial cells. Thorax. 2005;60(2):144-152.

24. Burgel PR, Nadel JA. Epidermal growth factor receptor-mediated innate immune responses and their roles in airway diseases. The European Respiratory Journal. 2008;32(4):1068-1081.

25. Takeyama K, Dabbagh K, Jeong Shim J, Dao-Pick T, Ueki IF, Nadel JA. Oxidative stress causes mucin synthesis via transactivation of epidermal growth factor receptor: role of neutrophils. The Journal of Immunology. 2000;164(3):1546-1552.

26. Kim V, Cornwell WD, Oros M, Durra H, Criner GJ, Rogers TJ, et al. Plasma Chemokine signature correlates with lung goblet cell hyperplasia in smokers with and without chronic obstructive pulmonary disease. BMC Pulmonary Medicine. 2015; 15(1):111. 